\title{
Design of expert system for train operational feasibility with Tsukamoto fuzzy inference system
}

\author{
Jumadi Jumadi, Wildan Budiawan Zulfikar, Dicky Andika Sulaeman, and Muhammad Ali Ramdhani* \\ UIN Sunan Gunung Djati Bandung, Department of Informatics, Jl. A.H. Nasution No. 105, Bandung, Indonesia
}

\begin{abstract}
Train is one of the most favorite mass transportation in the world. In 2017 train in Indonesia can bring about 341.605 passengers to many destinations. PT. Kereta Api Indonesia is a state owned enterprise that has responsibility to make sure that train is safe and works well. As we know that a train has several components to check. It is very difficult to identify whether a train is in a good condition or needs repairing. The purpose of this work is to proposes a model of operational feasibility by several main criteria: bogie, breaking system, boffer, electric coupler, and safety kit. In its experiment phase, this model uses Tsukamoto Fuzzy Inference System to decide that a train is in good condition or need repairing. In evaluation phase we compare this model with traditional method and this model shows exactly $99 \%$ of the same result. It is suggested for further work to include several methods such as Tsugeno and Mamdani fuzzy inference system.
\end{abstract}

\section{Introduction}

Currently, development of technology demands rapidly to apply technology in the environment with the maximum. In addition to helping, technology applications also make it easier for users. Therefore, the technology becomes appropriate technology $[1,2]$.

Therefore, there are many people's needs for an information technology-based system, including for decision makers requiring technology involvement [3], such as in the field of railway transportation in Indonesia in determining the feasibility of railway operational facilities.

The determination of the feasibility of the operation of the train means is the result of a series of inspections of train components that must meet the requirements of a roadworthy threshold, to ensure the train to be used or operated in good technical condition to safeguard the safety and comfort of its users. The purpose of this work is to proposed a model of operational feasibility using Tsukamoto Fuzzy Inference System to decide that a train is in good condition or need repairing [4-6]. Tsukamoto fuzzy inference system mainly used in a lot of filed and show that this method is effective and accurate [6-8].

\section{Experimental Method}

\subsection{Data Collecting}

The data attributes required by the system of determining the feasibility of the train facility with the fuzzy tsukamoto method obtained from a train depot in Indonesia as follows: bogie, boffer, breaking system, electric coupler, and safety tool kit. The source of data is a train inspector of each criterion is obtained by standard assessment of specification of each criterion. The standard criteria assessment as following table.

Table 1. Bogie Assessment.

\begin{tabular}{|c|c|c|c|c|c|}
\hline No & $\begin{array}{c}\text { Frame } \\
\text { (type and } \\
\text { condition) }\end{array}$ & $\begin{array}{c}\text { Shock } \\
\text { Absorber }\end{array}$ & $\begin{array}{c}\text { Bearing (type } \\
\text { and condition) }\end{array}$ & $\begin{array}{c}\text { Axle } \\
\text { Box }\end{array}$ & Pts \\
\hline 1 & $\begin{array}{c}\text { K5-TB398 } \\
/ \text { Good }\end{array}$ & Good & $\begin{array}{c}\text { Cat Ø119 } \\
\text { Tmp. } 1590 / \\
\text { Works }\end{array}$ & Good & 80 \\
\hline 2 & $\begin{array}{c}\text { K8 - } \\
\text { NT60/ } \\
\text { Good }\end{array}$ & Good & $\begin{array}{c}\text { Cat Ø119 } \\
\text { Wmp.1590/ }\end{array}$ & Good & 85 \\
\hline 3 & $\begin{array}{c}\text { K5 }- \\
\text { GT11/ }\end{array}$ & Good & $\begin{array}{c}\text { Sta Ø119 Tmp. } \\
1520 / W o r k s\end{array}$ & Good & 90 \\
\hline 4 & $\begin{array}{c}\text { K10- } \\
\text { TB1014/ } \\
\text { Good }\end{array}$ & Good & $\begin{array}{c}\text { Cat Ø119 } \\
\text { Tmp.1590/ } \\
\text { Works }\end{array}$ & Good & 95 \\
\hline
\end{tabular}

Bogie assessment describe in table 1. There are folling condition of train bogie with the currently points.

Table 2. Breaking System Assesment.

\begin{tabular}{|c|c|c|c|c|c|}
\hline No & Triangle & $\begin{array}{c}\text { Cyilinder \& } \\
\text { Control } \\
\text { Valve }\end{array}$ & $\begin{array}{c}\text { Rem } \\
\text { Blok }\end{array}$ & $\begin{array}{c}\text { Slack } \\
\text { Adjuster }\end{array}$ & Pts \\
\hline 1 & Works & $\begin{array}{c}\text { Works / } \\
\text { Single }\end{array}$ & Complete & Works & 85 \\
\hline 2 & Works & $\begin{array}{c}\text { Works / } \\
\text { Double }\end{array}$ & Complete & Works & 90 \\
\hline
\end{tabular}

Breaking system assessment describe in table 2 . This criteria is one of most important part of a train.

\footnotetext{
* Corresponding author : m_ali_ramdhani@uinsgd.ac.id
} 
Table 3. Boffer Assessment.

\begin{tabular}{|c|c|c|c|c|c|}
\hline No & $\begin{array}{c}\text { Boffer } \\
\text { height } \\
(\mathbf{m m})\end{array}$ & $\begin{array}{c}\text { Boffer } \\
\text { difference } \\
(\mathbf{m m})\end{array}$ & $\begin{array}{c}\text { Klow } \\
\text { Napless } \\
(\mathbf{m m})\end{array}$ & $\begin{array}{c}\text { Safety } \\
\text { Chain } \\
\text { (bh) }\end{array}$ & Pts \\
\hline 1 & 760 & 90 & 20 & 4 & 85 \\
\hline 2 & 775 & 90 & 20 & 4 & 90 \\
\hline 3 & 780 & 90 & 18 & 4 & 95 \\
\hline
\end{tabular}

Table 4. Electric Coupler Assessment.

\begin{tabular}{|c|c|c|c|c|}
\hline No & $\begin{array}{c}\text { Junction } \\
\text { Box }\end{array}$ & Cable & AC & Pts \\
\hline 1 & Covered & Proportional & Package & 85 \\
\hline 2 & Covered & Proportional & Split & 90 \\
\hline
\end{tabular}

Table 5. Tools Kit Assessment.

\begin{tabular}{|c|c|c|c|c|}
\hline No & $\begin{array}{c}\text { Hand } \\
\text { Break }\end{array}$ & $\begin{array}{c}\text { Emergency } \\
\text { Break }\end{array}$ & Toolkit & Nilai \\
\hline 1 & Works & Works & Complete & 90 \\
\hline
\end{tabular}

In observation phase, we obtained formed fuzzy members and membership function is through fuzzification stage. Then the next step by forming the rules IF-THEN and the next stage of the machine inference method tsukamoto in order to be able to change the input into output using the rules that have been determined. And the final stage of converting the output obtained from the inference stage becomes a firm value into an appropriate membership function at fuzzyfication.

\subsection{Fuzzification}

The input stage contains the fuzzyfication process that is the determination of the variables that affect the feasibility of the train facilities. There are 5 attributes of train station eligibility obtained from interviews and case studies at Depo Kereta Cirebon. The feasibility determination variable from the train scoring assessment data is made into fuzzy sets. For example, a K1-01006 first class train with following condition: bogie K5-TB398 = 80; breaking system $=85$; boffer $=85$; electric coupler $=85$; safety toolkit $=90$.

1. Bogie

Bogie variable condition with $\mathrm{x}=80$

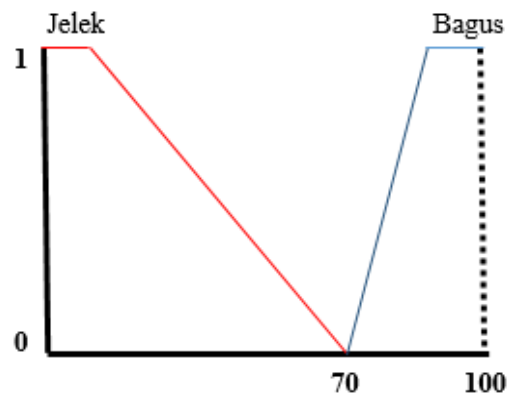

Fig. 1. Bogie Graphic Condition.

$$
\begin{array}{r}
\mu \text { Is good }[\times]=\left\{\begin{array}{cc}
0 ; & x \leq 70 \\
\frac{x-70}{100-70} ; & 70 \leq x \leq 100 \\
1 ; & x \geq 100
\end{array}\right. \\
\mu \text { Is good }[\times]=\left\{\begin{array}{cc}
\frac{80-70}{100-70}=\frac{10}{30}=0,33
\end{array}\right. \\
\mu \text { Jelek }[\times]=\left\{\begin{array}{cc}
0 ; & x \leq 70 \\
\frac{100-x}{100-70} ; & 70 \leq x \leq 100 \\
1 ; & x \geq 100
\end{array}\right. \\
\mu \text { Jelek }[\times]=\left\{\frac{100-80}{100-70}=\frac{20}{30}=0,67\right.
\end{array}
$$

2. Breaking System

Breaking system variable condiiton with $\mathrm{x}=85$

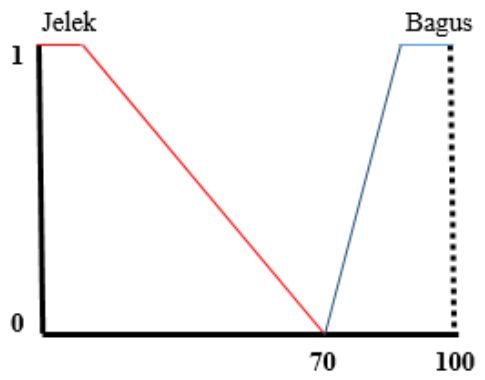

Fig 2. Breaking System Graphic Condition.

$$
\begin{gathered}
\mu \text { Is good }[\times]=\left\{\begin{array}{cc}
0 ; & x \leq 70 \\
\frac{x-70}{100-70} ; & 70 \leq x \leq 100 \\
1 ; & x \geq 100
\end{array}\right. \\
\mu \text { Is good }[\times]=\left\{\begin{array}{cc}
\frac{85-70}{100-70}=\frac{15}{30}=0,5 \\
\mu \text { Jelek }[\times]=\left\{\begin{array}{cc}
0 ; & x \leq 70 \\
\frac{100-x}{100-70} ; & 70 \leq x \leq 100 \\
1 ; & x \geq 100
\end{array}\right. \\
\mu \operatorname{Jelek~}[\times]=\left\{\frac{100-85}{100-70}=\frac{15}{30}=0,5\right.
\end{array}\right.
\end{gathered}
$$

\subsection{Rule Establishment}

After determining the variables and fuzzy set, then proceed the rule-making process in the form of IF-THEN. Rule is a knowledge structure that connects data information that has been known to other information so that it can be concluded.

The rule structure logically links one or more antaseden (also called the premise) located within the IF section with one or more consequences (also called conclusions) located within the THEN section.

Generally, a rule can have a plural premise linked to OR statements (conjunction) OR statements 
(disjunctions) or a combination of the two. Formation of rules is done by combining data from the condition of each train facility. Here is the rule that has been established:

1. [R1] IF bogie is good AND breaking system is good AND boffer is good AND electric coupler is good AND safety toolkit is good THEN feasible.

2. [R2] IF bogie has damaged AND breaking system is good AND and boffer is good AND electric coupler is good AND safety toolkit is good THEN unfeasible.

3. [R3] IF bogie has damaged AND breaking system has damaged AND boffer is good AND electric coupler is good AND safety toolkit is good THEN unfeasible.

4. [R4] IF bogie has damaged AND breaking system is good AND boffer has damaged AND electric coupler is good AND safety toolkit is good THEN unfeasible.

5. [R5] IF bogie has damaged AND breaking system is good AND boffer is good AND electric coupler has damaged AND safety toolkit is good THEN unfeasible.

6. [R6] IF bogie has damaged AND breaking system is good AND boffer is good AND electric coupler is good AND safety toolkit has damaged THEN unfeasible.

\subsection{Tsukamoto Inference System}

Inference is the process of converting a fuzzy input into a fuzzy output (crisp) by following the established rules (IFTHEN Rule). This stage determines the value of $\alpha$ and $z$ of each rule that has been established.

1. [R1] IF bogie is good AND breaking system is good AND boffer is good AND electric coupler is good AND safety toolkit is good THEN layak.

$$
\begin{gathered}
\propto=\min \mu(0,33 ; 0,5 ; 0,5 ; 0,5 ; 0,67) \\
\propto=\min \mu(0,33) \\
\propto=0,33 \\
\propto=\frac{(\mathrm{z}-70)}{100-70} \\
\mathrm{z}-70=(0,33 \times 30) \\
\mathrm{z}=70+(9,9) \\
\mathrm{z} 1=79,9
\end{gathered}
$$

2. [R2] IF bogie has damaged AND breaking system is good AND boffer is good AND electric coupler is good AND peraltan kesalamatan is good THEN unfeasible

$$
\begin{gathered}
\propto=\min \mu(0,67 ; 0,5 ; 0,5 ; 0,5 ; 0,67) \\
\propto=\min \mu(0,5) \\
\propto=0,5 \\
\propto=\frac{(100-\mathrm{z})}{100-70}
\end{gathered}
$$

$$
\begin{gathered}
100-\mathrm{z}=(0,5 \times 30) \\
\mathrm{z}=100-(15) \\
\mathrm{z} 2=85
\end{gathered}
$$

3. [R3] IF bogie has damaged AND breaking system has damaged AND boffer is good AND electric coupler is good AND safety toolkit is good THEN unfeasible.

$$
\begin{gathered}
\propto=\min \mu(0,67 ; 0,5 ; 0,5 ; 0,5 ; 0,67) \\
\propto=\min \mu(0,5) \\
\propto=0,5 \\
\propto=\frac{(100-\mathrm{z})}{100-70} \\
100-\mathrm{z}=(0,5 \times 30) \\
\mathrm{z}=100-(15) \\
\mathrm{z} 3=85
\end{gathered}
$$

Tabel 6 describ summary rule in order to determine $\alpha$ dan $\mathrm{z}$ value including $\mathrm{R} 4, \mathrm{R} 5$, dan R6 that not explain in this article.

Table 6. Inference Calculation.

\begin{tabular}{|c|c|c|c|}
\hline Rule & $\boldsymbol{\alpha}$ & $\mathbf{z}$ & $\boldsymbol{\alpha} * \mathbf{z}$ \\
\hline $\mathrm{R} 1$ & 0,33 & 79,9 & 26,367 \\
\hline $\mathrm{R} 2$ & 0,5 & 85 & 42,5 \\
\hline $\mathrm{R} 3$ & 0,5 & 85 & 42,5 \\
\hline $\mathrm{R} 4$ & 0,5 & 85 & 42,5 \\
\hline $\mathrm{R} 5$ & 0,5 & 85 & 42,5 \\
\hline R6 & 0,33 & 90,1 & 29,733 \\
\hline Total & 2,66 & & 266,1 \\
\hline
\end{tabular}

\subsection{Defuzzification}

The defuzzyfication stage is the last stage of the fuzzy logic tsukamoto technique. Changing the fuzzy output of the inference becomes a firm value using the membership function that corresponds to the fuzzyfication. This stage is to determine the final $\mathrm{z}$ using the average value. The way the calculation is to divide the number of $\alpha^{*} \mathrm{z}$ with the number of $\alpha$ (alpha).

$$
\begin{gathered}
\mathrm{Z}=\frac{\sum(a * z)}{\sum a} \\
\mathrm{Z}=\frac{266,1}{2,66}
\end{gathered}
$$




$$
\mathrm{Z}=85
$$

The final $\mathrm{z}$ value by dividing the sum of $\alpha^{*} \mathrm{z}$ by the sum of $\alpha$ (alpha) is 85 . Then the train K1-01006 from the examination result by the assessment of each criterion (train component) using the tsukamoto fuzzy method calculation yields the final $\mathrm{z}$ value 85 that the train is worth operate.

\section{Result and Discussion}

Performance test of decision support system to determine the feasibility of this train facility, is done by comparing the result done in the application with the calculation result which is done conventionally. According to evaluation list, we found that this proposed model has exactly $99 \%$ accuration value. It means that Tsukamoto inference system works effectively [9] in this model $[10,7,11,12]$.

\section{Conclusion}

Tsukamoto inference system is an effective method to solve this complex model. This method has a high number of accuration with $99 \%$. In further work, we suggest to implement others inference system such as Mamdani and sugeno. The determine factor should be improve in order to convince and satisfy the stake holder.

\section{References}

1. M. A. Ramdhani, H. Aulawi, A. Ikhwana, and Y. Mauluddin, "Model of green technology adaptation in small and medium-sized tannery industry," $J$. Eng. Appl. Sci., vol. 12, no. 4, pp. 954-962, (2017)

2. C. Alias, F. E. A. Olalla, A. Potechin, and B. Noche, "Comparing methods of technology benefit assessment regarding their applicability to transportation and logistics," in 2018 IEEE International Conference on Smart Manufacturing, Industrial \& Logistics Engineering (SMILE), pp. 21-26. (2018)

3. W. B. Zulfikar and N. Lukman, "Perbandingan Naive Bayes Classifier Dengan Nearest Neighbor Untuk Identifikasi Penyakit Mata," J. Online Inform., vol. 1, no. 2, pp. 82-86, Dec. (2016)

4. T. Hastono, A. J. Santoso, and Pranowo, "Honey yield prediction using Tsukamoto fuzzy inference system," in 2017 4th International Conference on Electrical Engineering, Computer Science and Informatics (EECSI), pp. 1-6. (2017)

5. T. S. Putri and F. Ramdani, "Reliability testing using hybrid exploratory basis of tour and fuzzy Inference System Tsukamoto," in 2017 International Conference on Sustainable Information Engineering and Technology (SIET), pp. 176-183. (2017)

6. D. M. N. Fajri, W. F. Mahmudy, and Y. P. Anggodo, "Optimization of FIS Tsukamoto using particle swarm optimization for dental disease identification," in 2017 International Conference on Advanced Computer Science and Information Systems (ICACSIS), pp. 261-268. (2017)

7. I. Wahyuni and F. Utaminingrum, "Error numerical analysis for result of rainfall prediction between Tsukamoto FIS and hybrid Tsukamoto FIS with GA," in 2016 International Conference on Advanced Computer Science and Information Systems (ICACSIS), pp. 365-372. (2016)

8. R. Shoureshi and Zhi Hu, "Tsukamoto-type neural fuzzy inference network," in Proceedings of the 2000 American Control Conference. ACC (IEEE Cat. No.00CH36334), pp. 2463-2467 vol.4. (2000)

9. N. I. Kurniati, H. Mubarok, and A. Reinaldi, "Rancang Bangun Sistem Pakar Diagnosa tingkat Depresi Pada Mahasiswa Tingkat Akhir Menggunakan Metode Fuzzy Tsukamoto(Studi Kasus : Universitas Siliwangi)," J. Online Inform., vol. 2, no. 1, p. 49, Jul. (2017)

10. B. S. Ardika, A. H. Setianingrum, and N. Hakiem, "Funding eligibility decision support system using fuzzy logic Tsukamoto: (Case: BMT XYZ)," in 2017 Second International Conference on Informatics and Computing (ICIC), pp. 1-7. (2017)

11. V. R. R. Agustin and W. H. Irawan, "Aplikasi Pengambilan Keputusan dengan Metode Tsukamoto pada Penentuan Tingkat Kepuasan pelanggan," CAUCHY, vol. 4, no. 1, p. 10, Nov. (2015)

12. H. Istiqlaliyah and R. A. Ramadhani, "Sistem Kontrol Frekuensi Putar Motor Pada Cooling Pad Menggunakan Metode Fuzzy Tsukamoto," Simetris J. Tek. Mesin, Elektro dan Ilmu Komput., vol. 8, no. 2, p. 755, Nov. (2017) 